\title{
The Changing Role of the Primary Care Physician in Managed Care
}

\author{
Gregg L. Mayer*, Ph.D. \\ Shigeru Tanaka ${ }^{\dagger}$, M.A., M.B.A.
}

\begin{abstract}
The rapid spread of managed care is a major reason behind the slowing of the health care cost growth rate in the US. Managed care organizations (MCOs), particularly HMOs, are increasingly being held accountable for the quality of health care delivery by their contract providers, and are reporting more information about the quality of health care delivered. HMOs have introduced the use of management tools such as evidence-based guidelines, gatekeeping, and capitation to improve the cost-effectiveness of care delivered by their contract providers.

Primary care physicians (PCPs) are playing an important role in the delivery of managed health care, and now bear part of the financial risk through mechanisms such as gatekeeping and capitation. This paper looks at some recent reports of PCP satisfaction with this new role. PCPs in the role of gatekeeper were found to have lower satisfactions due to increased administrative work associated with gatekeeping, though most physicians felt that quality of care was unaffected. About half of PCPs are reported to have at least one capitated contract, far more than specialists. Larger physicians groups were also found to be more likely to have capitated contracts than smaller groups. PCPs were generally found to be less satisfied with treating their patients covered by capitated contracts than in their practice as a whole, though satisfaction increased with increasing proportion of capitated patients. However, another study showed that total physician visits, hospital days, and total costs were unaffected by physician compensation method. This suggests that it is the system of health care delivery and not care at the level of the physician/patient interaction that is affected by managed care.
\end{abstract}

Keywords: Managed care, HMO, Primary care physicians (PCPs)

Gate keeping, Capitation payment

* Gregg Mayer and Co.

† The Graduate School of Business Administration, Keio University 


\section{Introduction}

Managed care has rapidly become the dominant form of health care in the US. In 1980 only $5 \%$ of those employees covered by private health insurance were in HMOs, the only type of managed health care available at the time. The remainder were in traditional fee for service plans. By 1995, privately insured employees covered by either PPOs or HMOs, the dominant types of managed care organizations (MCOs) had grown to $67 \%$. In addition, indemnity insurance plans covering most of the remaining $33 \%$ of employees use utilization review, pharmaceutical benefits management and other managed care technologies to control costs. HMOs have been shown to provide more cost-effective health care that is equal in quality to or better than traditional fee for service health insurance plans. MCOs are the combination of an insurance product and utilization review capability that contracts with health care providers, chiefly physicians and hospitals, to provide managed health care to the insured or health plan member. The degree to which payers and providers work together is dictated by the contract between payer and provider. These contracts dictate the providers' ability to make treatment decision autonomously, what compensation the provider will receive, and how utilization review is performed (see review by Mayer, and Tanaka, 1997). This evolution from pure fee for service to managed care is at least partly responsible for reducing the annual increase in national health care spending to $1.2 \%$ in 1996, the lowest rate in more than 20 years (Ginsburg, and Gabel, 1998).

Increasingly, MCOs are being asked to report concrete results of care provided to employers, members, and providers. Interstudy (1998) surveyed HMOs for trends in the content of their reports to purchasers, providers and others over the period from 1993 to 1997. Not surprisingly, in 1993, 95\% of HMOs responding reported cost and utilization data, almost equal to the $98 \%$ response in 1997 . The recent rise in HMO popularity is due to their ability to control health care spending. More recently however, HMOs have come under increased scrutiny as to the level of member satisfaction and quality of health care provided. In 1997, 96 $\%$ of HMOs reported member satisfaction data versus only $45 \%$ in 1993 . HEDIS (Health Plan Employer Data and Information Set; a set of defined parameters used by HMOs to measure performance, administered by the National Committee on Quality Assurance) or other report card measures were being reported by $93 \%$ of HMOs in 1997, up from 65\% in 1993 . HEDIS includes several measures having to do with quality of care provided, particularly primary care. Recently more direct measures of quality of health care are being demanded from HMOs. For example, in $199737 \%$ of HMOs reported changes in health status of its members, up from only $10 \%$ in 1993 . In the eyes of the employer, the public, and the member, the HMO is increasingly being held accountable for the health care of its members.

In response to this increased responsibility for member health care MCOs, particularly HMOs, have introduced numerous changes in the way medicine is practiced. Quality management in MCOs is charged with maintaining both quality of medical care as well as appro- 
priateness of utilization. MCOs have worked to define cost-effective care for their contract providers through the production, publication, and dissemination of clinical care guidelines designed to prevent and treat common diseases in the outpatient clinic. These changes center around the rise of the primary care physician (PCP) as a care manager or gatekeeper for all care provided. MCOs have also introduced payment methodologies for their contract provider groups that are designed to incent cost-effective behavior. Through the contract, MCOs have passed varying degrees of financial responsibility for providing care for their members, on to the providers. With this financial responsibility comes both the potential for increased risk and reward. This article describes selected recent reports from the literature describing these changes and how they effect the practice of medicine by PCPs under managed care.

\section{Use of Guidelines}

Many American academic medical societies publish clinical guidelines. These are often called "standards of care" and serve as a common denominator for patient care. In addition, since HMOs must report results of the health care of its members, many MCOs have adopted more thorough clinical guidelines for their member physicians to follow. These guidelines also describe the most cost-effective methods to treat common disorders. These may be purchased from consulting or actuarial firms (Anders, and McGinley, 1998) or developed internally by physicians. Clinically they are based on academic standards of care and other published reports, thus they are frequently referred to as evidence-based medicine. In addition to standard methods of treatment, MCO guidelines will often prescribe necessary testing, procedures, and hospital lengths of stay. Often, an MCO or medical group will use an outside guideline as a starting point for developing an internal guideline. The adoption and acceptance by physicians of guidelines is challenging, due to the natural independence of the practice of medicine, and has been derided by some as "cookbook medicine".

Guidelines for managing chronic disease are especially important to MCOs due to the high cost and long term nature of these diseases. One recent study in an HMO setting showed that a diagnosis of chronic disease will result in an increase in expected cost per member of between $80 \%$ and $300 \%$, depending on age, sex, and the illness. (Fishman et al., 1997). The two most common disease targeted are asthma and diabetes with approximately $60 \%$ of HMOs developing disease management guidelines (Interstudy, 1997). These are both chronic diseases where proper primary care can result in avoiding expensive inpatient care and improving patient functional status. Adherence to evidence-based guidelines in treating these and other chronic diseases is extremely important to the patient and the $\mathrm{MCO}$, in addition to the provider. Gathering data on cost and quality of care, as well as outcomes, before and after implementation of such guidelines is imperative to measuring their effects. Staff and group model HMOs have greater ability to control cost and quality of care provided due to the exclusive nature of the relationship between provider and MCO. These organizations have collected data and evaluated internal quality for years, since the patient charts, the ultimate source of data, is present within the walls of the HMO. 
Recently, through the use of increasingly sophisticated information systems, IPA and network model HMOs are now also finding it easier to measure the quality of care provided by its providers. In the past, this was accomplished exclusively through extensive random chart reviews of contract providers. For example, United Health Care (Minnetonka, Minnesota) has begun using its claims data to examine the prescribing habits of its contracted provider physicians. They found that in many cases medical standards of care established by academic medical societies were being followed at low rates. For example, United evaluated the prescribing habits of 1,600 cardiologists in four states. The American College of Cardiology recommends that heart attack patients receive beta-blockers to help prevent a second heart attack. United found that only $37 \%$ of such patients in Ohio had actually received the drugs within 60 days of a heart attack. Some patients don't like beta blockers since they have some side effects, but at the same time many experts think that $37 \%$ is too low. Similarly, ACE inhibitors are recommended to treat patients with chronic heart failure. Yet, only $50-63 \%$ of such patients were found to be taking the drugs in some states, whereas in Colorado $70 \%$ were taking them. In another example, roughly one million Americans have atrial fibrillation, a type of irregular heartbeat that can cause stroke. The American Heart Association recommends using anticoagulants to help prevent stroke. But United found that in three states, only 12-25 $\%$ of patients were receiving them, compared to $50 \%$ in Ohio. Physician sentiment about these evaluations is mixed. The HMO plans to expand its analysis to other specialties and eventually make the data available to its members (Burton, 1998).

\section{Effect of Managed Care on Primary Care}

PCPs are generally defined to include general practitioners, family practice physicians, physicians in general internal medicine, and pediatricians. In some cases OB/GYNs may be included as well, since many women receive their primary care annually at the time of their cervical cancer screening. The definition of primary care generally includes routine comprehensive physical exams, coordination of patients' general medical care, and treating common illnesses and conditions. Simon et al. (1997) looked at the effects of managed care on the relative time spent between primary and specialty care. The authors used data from the AMA's annual telephone survey to look at two questions:

1) Does the physician offer primary care services?

2) If so, what proportion of time in the past week was devoted to providing these services?

Not surprisingly, almost all PCPs offered primary care services in both 1991 and 1995. However, the percent of time PCPs spent in primary care activities increased from $70.6 \%$ in 1991 to $76.9 \%$ in 1995 . At the same time, the number of specialists offering primary care services declined from $37.3 \%$ in 1991 to $32.7 \%$ in 1995 . The percent of time those specialists spent in primary care activities declined slightly from $12.3 \%$ in 1991 to $10.4 \%$ in 1995 . During this period, managed care was growing rapidly. These data are consistent with results of Donelan et al. (1997) where in a survey of 2,000 doctors in 1995, 40\% of PCPs said they plan to provide more primary care services over the next three years. 
Simon et al. (1997) also looked at the percent of physician time spent in primary care versus the relative involvement in managed care. They found that PCPs with no managed care contracts spent an average of $73 \%$ of their time in primary care, while those with noncapitated and capitated managed care contracts spent $75 \%$ and $78 \%$ of their time, respectively, in primary care. At the same time, specialists with no managed care contracts spent $20 \%$ of their time in primary. care activities, while those with non-capitated and capitated managed care contracts spent only $6 \%$ and $13 \%$ of their time, respectively, in primary care. This is consistent with the relatively higher cost of specialty versus primary care physicians in the US. One of the ways that MCOs have tried to reduce health care costs is to encourage more health care provision, including primary care, by PCPs rather than the relatively more expensive specialists. Other findings showed that among specialists, obstetrics/gynecology and emergency medicine had the largest number of respondents offering primary care, $67 \%$ and 78 $\%$ respectively, though the amount of time those offering primary care actually spent in primary care activities, was only $31 \%$ and $23 \%$.

The authors concluded that there has been a recent decline in specialist involvement, and an increase in PCP involvement, in primary care coinciding with increasing physician involvement in managed care.

\section{Primary Care Physician as Gatekeeper}

The role of the primary care physician (PCP) has expanded in the era of managed care. Many MCOs, particularly HMOs, assign members to a specific PCP who plays the role of gatekeeper. Webster's Dictionary provides two definitions for this word:

1) "one that tends or guards a gate"

2) "supervisor or monitor"

Both definitions are probably applicable to the role of the PCP in MCOs. One of the suspected causes of the historical high cost of medical care in the US is unnecessary care. This includes redundant exams or tests, unnecessary specialty physician visits, unneeded medications, and elective procedures that are relatively high cost, but provide relatively low benefit. In the role of gatekeeper definition \#1, the PCP tries to reduce these activities.

At the same time, in the role of definition \#2, the PCP plays a supervisor role for the entire spectrum of services needed by the patient. In this role, the PCP ensures that the patient receives all needed care, serving as the central referral point for needed medications, tests, specialty referrals, hospitalizations, home care, and psychological care needs. One of the means by which HMOs have reduced health care expenditures is by reducing expensive specialty care and hospitalization, through increased preventive and routine care delivered in the outpatient setting (Greenfield et al., 1992). A strong gatekeeping function is one of the systems in HMOs that enables this cost-saving shift in care. 


\section{Physician Attitudes on the Effect of Gatekeeping}

Halm et al. (1997) surveyed 202 physicians who were participating in two Blue Cross / Blue Shield plans in the Boston area to assess physician attitudes about the effects of gatekeeping compared to traditional care. Employees of Mass General Hospital could choose between a fee for service (FFS) plan without a gatekeeper, and one with. The gatekeeping responsibilities were principally to authorize emergency visits, visits to specialists, and hospitalizations. The plan with the gatekeeper was less expensive, but otherwise the benefits were the same. The authors examined the effect of gatekeeping on physician attitudes towards administrative work, quality of care, and appropriateness of resource use and cost. This study is unique in that it controlled for all other variables and examined purely the effect of gatekeeping.

They found that gatekeeping had a negative effect on administrative work, that is it increased physician and staff paperwork, as well as telephone work, and increased the difficulty of specialty referrals. They found mixed results on patient care. Gatekeeping had a positive effect on physicians' knowledge of a patient's overall care, coordination of care, and frequency of preventive care. It had a negative effect on the physician-patient relationship, time spent with patients, freedom in clinical decisions, and ease in ordering expensive tests. Doctors were mixed on the effect on appropriate use of resources. Doctors thought gatekeeping had a positive effect on preventive services use and emergency room use. They also felt it had a negative effect on appropriate use of hospitalization, specialist care, lab tests, and medication choice.

Finally, the survey asked about the effect of gatekeeping on overall cost and overall quality of care delivered. Eighty-eight percent of physicians believed that gatekeeping had a positive effect on reducing cost. On the issue of overall quality of care, $74 \%$ of doctors thought that quality was unaffected, $6 \%$ thought gatekeeping had a positive effect, while $20 \%$ thought it had a negative effect. Overall, more doctors felt that gatekeeping had a negative effect than felt it had a positive effect, but $74 \%$ thought it had no effect on quality of care.

\section{Extent Of Managed Care And Capitation Among PCPs}

Simon, and Emmons (1997) used 1995 AMA survey data to examine the extent of managed care contracts among US physicians. This is compensation from the MCO or insurance company to a physician group, not the compensation from the medical group to the individual physician. Their results showed that $84 \%$ of all physicians' practices had at least one managed care contract.

Capitation is the payment of a single charge per member per month from the MCO to the contracted provider group to provide all necessary care for that member. HMOs frequently compensate medical groups on a capitated basis. If the member goes to a participating 
provider's office for care, he pays only and a small copayment for each visit. Simon, and Emmons (1997) found that capitation is used more often for compensating PCPs, than specialists. The AMA survey data showed that $50.2 \%, 47.8 \%$, and $63.8 \%$ of general family practice, general internal medicine, and pediatric physicians, respectively, had one or more capitated contracts, compared to $32 \%$ of all physicians as a whole. The specialty with the smallest percentage of physicians under capitation was psychiatry, with only $17 \%$ having one or more capitated contracts, whereas internal medicine subspecialists (including cardiologists, gastroenterologists, etc.) had the largest percentage, with $32.7 \%$ having one or more.

The authors also reported on the effect of group size on capitation. Only $26.6 \%$ of solo physicians' practices had one or more capitated contract, increasing to $75.2 \%$ of groups of 51 or more. Among the physicians with capitated contracts, Simon and Emmons also reported on the portion of practice revenue capitated. In 1995, an average of $19.2 \%$ of physician practice revenue was capitated. PCPs had a slightly higher level, at $21.5 \%, 19.2 \%$, and $23.7 \%$ of revenue capitated for general family practice, general internal medicine, and pediatric physicians. Therefore even among PCPs, the total portion of practice revenue that is capitated is still relatively small.

There have also been studies of physician group or practice compensation by MCO type. In group or staff model HMOs, $60 \%$ of plans compensated physician groups using salaries, about $35 \%$ through capitation, and about $5 \%$ using FFS. Whereas, in IPA and network HMOs, about $58 \%$ of plans compensate physician groups through capitation, about $38 \%$ use FFS, and the remaining $5 \%$ or so use salary. About $92 \%$ of PPOs compensate physician groups through FFS, with only $8 \%$ or so using capitation (Kongstvedt, 1997, Chapter 8 ). Once again, these data refer to payments from the MCOs to the physician group or practice, and not to compensation by medical groups of individual physicians.

\section{Effect of Capitation on Physician Satisfaction}

Kerr et al. (1997) compared PCP satisfaction with quality of care for patients covered by capitated contracts versus patients in their overall practice. The goal of the study was to determine the effect of capitated compensation on the quality of care at the individual physician/patient level. They surveyed 910 in 89 medical groups that had capitated contracts in California, examining four aspects of care.

In "your relationships with patients", $71 \%$ of PCPs responded that they were Very or Somewhat Satisfied with capitated patients versus $88 \%$ in their overall practice. Similarly, 64 $\%$ said they were Very or Somewhat Satisfied with the "quality of care you are able to provide" to capitated patients versus $88 \%$ in their overall practice. The biggest difference was in PCPs' "ability to treat patients according to your own best judgement", where $51 \%$ felt Very or Somewhat Satisfied with capitated patients versus $79 \%$ in their overall practice. The smallest difference was in "ability to obtain specialty referrals whenever you feel they are necessary", 
where $50 \%$ of PCPs responded they were Very or Somewhat Satisfied with their capitated patients versus $59 \%$ in their overall practice. All four differences were statistically significant.

The authors also analyzed the data by type of physician group and found that IPA members were statistically less satisfied on all four measures than medical group practice members. Also, salaried PCPs were more satisfied than PCPs receiving either a per patient capitated fee or discounted fee for service-based compensation. These results suggest that removing any economic incentive from the individual physician/patient relationship improves the physician's perceived quality of care under capitation.

Finally, satisfaction with all four measures was relatively higher on all four measures among groups with a higher proportion of capitated patients compared to groups with a lower proportion. This suggests that medical groups with larger proportions of capitated patients have developed practice styles and systems consistent with capitated reimbursement.

\section{Compensation method and use of health services}

Conrad et al. (1998) examined the influence of the compensation of PCPs on the use and cost of health care services provided. They surveyed 865 PCPs in Washington who were affiliated with one or more MCOs that serve 200,931 adult members in the area. Almost $90 \%$ were family practitioners. The four plans consisted of a staff model HMO, a group model HMO, a network HMO, and a PPO. All four plans had extensive utilization review. They linked these results to cost and utilization data from the four major MCOs in the area, using weighted least squares and random effects regression, examining costs per member per year, encounters (outpatient and inpatient combined) per year, and hospital days per year. Among responding groups, $70 \%$ were PCPs only and $30 \%$ were multispecialty groups. Forty-eight percent of groups had 3-5 PCPs, $26 \%$ had 6-19 PCPs, and $26 \%$ had 20 or more PCPs.

Ninety-six percent of the enrollees in the plans were covered under contracts with MCOs that placed the PCP groups at risk through a variety of capitation and withhold arrangements, and discounted fee for service. (Withholds are a percentage of capitated contract fees "withheld" from monthly payments as a form of insurance against cost overruns. If costs are within budget, these fees are returned to the group at the end of the year. If costs exceed budget these fees may be retained by the HMO to help pay for the cost overrun.) The individual physicians in the groups were paid by a combination of salaries and production-based methods, whereby increasing productivity increases compensation. Examining individual PCP compensation, $18 \%$ of physician groups compensated their individual physicians using salary only, $16.7 \%$ used at least half salary, $16.7 \%$ used at least half production-based compensation, and 45 $\%$ used fully production-based compensation. None of the groups in this survey used capitation to compensate individual physicians.

Results showed that there was no significant difference between the different compensation 
groups in total physician visits, total hospital days, nor per member per year costs. Even costs of patients diagnosed with chronic disorders such as asthma, congestive heart failure, and hypertension were found to have no significant differences in cost and utilization under different physician compensation methods. Follow up interviews with physicians and MCO administrators suggested too that treatment decisions were based on clinical indication, not on financial incentive. It was felt that physicians do respond to financial compensation incentives, but that these tend to affect work productivity, not individual patient treatment decisions. The authors cite previous studies that also suggest physician productivity is associated with financial incentives.

In contrast, member (patient) age, gender, plan benefit level, and doctor age were found to be significantly positively related to all three cost and utilization measures. A $10 \%$ increase in member age was found to be associated with a $7.8 \%$ increase in total cost. Women enrollees had $77 \%$ higher costs and $4.7 \%$ more visits than men. Members with older PCPs were found to have lower costs and utilization.

This study only examined groups of three or more physicians. Therefore it is unclear whether or not these results can be extrapolated to solo or duo practice physicians. In physician groups, risk is minimized by pooling revenues and costs and physician compensation can be relatively isolated from MCO contract revenue. In contrast, in solo or duo practices physician compensation is essentially equivalent to the $\mathrm{MCO} /$ provider contract provisions, since there is little or no opportunity to spread the risk among partners.

\section{Discussion}

American health insurance in the private sector, and increasingly in the public sector, is managed care. While modern HMOs were created largely in the 1970 s to contain health care costs, they have now become jointly responsible for the health care of their members, a role that physicians alone bore before the era of managed care. HMOs have in turn passed some of the financial responsibility of providing care on to providers, giving them more potential risk and reward, depending on their performance. Increasingly, the PCP bears a larger role in managing the health care of their patients by coordinating the use of all health care resources. HMOs have supported this management role through the use of guidelines and clinical protocols for PCPs, backed up by financial incentives. Recently, a number of studies have looked at various aspects of this rise in importance of the PCP.

MCOs have expanded the role of the PCP to one of gatekeeper, where they must manage the total health care of their assigned members. With this responsibility comes an increase in administrative burden, which some physician don't like. Many patients also dislike the intrusion of MCOs into their ability to freely see the physician of their choice. However in one study, gatekeeping did increase the physicians' knowledge of their members' health status, coordination of care, and frequency of preventive care. Most doctors agreed that gatekeeping 
is more cost-effective and had no effect on quality of care provided.

MCOs are increasingly using capitated contracts with their physician provider groups. More than half of all PCP groups now have at least one capitated contract. Capitation aligns the financial incentives of MCO and provider towards the same goal of keeping members healthy and out of the hospital, since outpatient preventive and primary care are substantially less expensive than inpatient care. However, Kerr's paper suggested that PCPs are less satisfied with a number of aspects of care with their capitated patients versus their overall practice. These included quality of care provided and ability to treat patients according to their own judgement. These results suggest that while most PCPs are still not used to treating capitated patients, results will improve with time, since groups with the most capitated patients showed the highest satisfaction.

Conrad's results show that individual physician compensation, whether production-or salary-based, had no effect on individual patient costs nor utilization. Therefore, it is probably the productivity of physician groups and the systems they develop under the incentives of managed care contracts that account for the lower costs of health care in HMOs. As mentioned before, physician satisfaction with capitation increased with increasing proportion of capitated contracts in Kerr's paper. Larger groups with more contracts can certainly better afford the administrative support systems necessary to handle the additional paperwork and administration of managed care contracts.

In the future, there will likely be increased penetration of MCOs and new methods of physician compensation. Information systems will allow increased scrutiny of the results of individual members, not just populations. As employers and consumer continue to demand more information on outcomes from MCOs, MCOs in turn will increasingly mine these results from their information systems. As these results are shared more openly, MCOs and physicians will be challenged to continue to develop new creative financial incentives that simultaneously encourage both increasing quality and cost-effectiveness.

\section{Acknowledgements}

The authors would like to thank Professor Thomas G. Rundall for his critical review of the manuscript and Ms. Fumie Wakamatsu for her translation of the abstract into Japanese.

\section{References}

Anders, George, and Laurie McGinley (1998) "Actuarial Firm Decides Just How Long You Spend in the Hospital," Wall Street Journal. July 8, 1998.

Burton, Thomas M. (1998) "An HMO Checks up on its Doctors' Care And is Disturbed Itself," Wall Street Journal. July 8, 1998, page 1.

Conrad, Douglas A., et al. (1998) "Primary Care Physician Compensation Method in Medical Groups," Journal 
of the American Medical Association. 279:853-858.

Donelan, Karen, et al. (1997) "The New Medical Marketplace: Physicians' Views," Health Affairs. 16(5):139148.

Fishman, Paul, et al. (1997) "Chronic Care Costs in Managed Care," Health Affairs. 16(3): 239-247.

Ginsburg, Paul B., and Jon R. Gabel (1998) "Tracking Health Care Costs: What's New in 1998?" Health Affairs. 17(5): 141-146.

Greenfield, Sheldon, et al. (1992) "Variations in Resource Utilization Among Medical Specialties and Systems of Care: Results of the Medical Outcomes Study," Journal of the American Medical Association. 267:16241630.

Halm, Ethan, et al. (1997) "Is Gatekeeping Better Than Traditional Care?" Journal of the American Medical Association. 278: 1677-1681.

Interstudy (1997) "HMO Industry Report 7.2" Minneapolis: Interstudy Publications.

Interstudy (1998) "HMO Industry Report 8.1" Minneapolis: Interstudy Publications.

Kerr, Eve A., et al. (1997) "Primary Care Physicians' Satisfaction with Quality of Care in California Capitated Medical Groups," Journal of the American Medical Association. 278: 308-312.

Kongstvedt, Peter R. (1997) Essentials of Managed Care. Gaithersburg, Maryland: Aspen Publishers, Inc.

Mayer, Gregg L., and Shigeru Tanaka (1997) "Managed Care Development and Innovation in the US, and Their Policy Implications for Japan," Journal of Health Care and Society. 7(1): 109-127.

Simon, Carol J., et al. (1997) "The Provision of Primary Care: Does Managed Care Make a Difference?" Health Affairs. 16(6): 89-98.

Simon, Carol J., and David W. Emmons (1997) "Physician Earnings at Risk: An Examination of Capitated Contracts," Health Affairs. 16(3):120-126. 


\title{
マネージドケアによって変わりつつある プライマリ・ケア医師の役割
}

\author{
グレッグ・L・メイヤー* \\ 田中滋 ${ }^{\dagger}$
}

\begin{abstract}
米国における医療費の伸び率が低下した主な原因の一つは，マネージドケアの急速な拡大である。 マネージド・ケア組織 $(\mathrm{MCO})$, 特にHMOは, 契約した医療提供者による医療供給の質に対して 責任を持つよう求められてきている。またMCOは，供給される医療の質にかかわる情報を公表す るようになりつつある。HMOは，契約医療提供者が供給する医療の費用対効果を向上させるため に, 科学的根拠を持った（エビデンス・ベイスド）ガイドライン, 振り分け機能（ゲイトキーピン グ)，人頭払いなどの管理ッールを導入してきた。

「管理された医療の供給」にあたっては，プライマリ・ケア医師が重要な役割を果たす。今や彼 らは, 振り分け機能や人頭払いなどの仕組みを通じて, 財政的なリスクの一端をむ担っている。本 論文は，こうした新しい役割に対するプライマリ・ケア医師の満足度について，最近の報告をいく つか紹介する。ほとんどのプライマリ・ケア医師は, 振り分け機能によって医療の質が影響を受け るとは感じていないが，ゲイトキーパーとしての役割に伴う事務作業量增加のせいで, 満足度が低 下している様子が明らかになった。プライマリ・ケア医師のおよそ半数が，（保険会社との間に） 人頭払いの契約を少なくとも一件は結んでいる。この值は専門医よりはるかに大きい。また，多人 数からなる医師グループほど，人頭払いの契約をすつ確率が高い。一般に，人頭払い契約になって いる患者に対してプライマリ・ケア医師が感じる診療の満足度は，患者全体と比べると低いものの， 人頭払いの患者比率が大きいほど満足度も高くなっていた。しかし, 受診回数・入院日数・総費用 は，医師への報酬支払い方法とは無関係であるとの調查むある。したがって，医療供給システム全 体はマネージドケアによって影響を受けるとはいえ，医師・患者間の直接的関係のレベルはさほど 影響されないと考えられる。
\end{abstract}

キーワード : マネージドケア, HMO, プライマリ・ケア医師

振り分け機能（ゲイトキーピング）, 人頭払い

* Gregg Mayer and Co.

†慶應義塾大学大学院経営管理研究科 